\title{
The Value and Limitations of Open Access On-line Medical Literature in an Era of Jurassic Information Consumption
}

\section{Edwin Earl Gaar}

Professor of Surgery, Academic Advisory Dean, University of Louisville

In 1543 Copernicus developed a radical and revolutionary idea that the earth indeed was not the center of the universe. He chose to publish and accept the wrath of society, as opposed to keeping his new-found knowledge within safe circles. At the same time he therefore allowed his theory to withstand the test of time. This certainly exemplifies the multi-faceted role of the physician/scientist, whose obligation is the creation, conservation and dissemination of medical knowledge to alleviate illness and suffering of mankind.

Over the past 25 years, our society has undergone an information explosion parallel with the development and refinement of both the personal computer and the internet. History will show these to be the most significant, long lasting achievements of the late $20^{\text {th }}$ century. I have been fortunate to see this revolution first hand having performed my first medline search on a first generation DOS based IBM PC via a telephone modem in 1984. At that time, a two megabyte hard disc drive was considered exotic. Today, the ipad that I carry to work each day today contains more computing power than the first Apollo capsule that went to the moon. It contains more books and articles than I can fit on my desk. It allows me access to the entire internet at will. The internet has exploded to the point that most children in this country have ready access to it, and use it as a toy. Virtually every radio and television commercial contains the phrase "for more information go to www..." Many lay public consider information posted on the internet as "gospel".

My interest in this subject has recently been heightened as I am in the final stages of completing an electronic textbook of surgery. For years being involved in medical student education, specifically third year medical student education in surgery, I have been un-happy with textbooks available to my students. They have an eight week rotation and are required to ingest an over-whelming volume of material. Most standard textbooks literally cannot be read in eight weeks cover-tocover and other "smaller" books lack detail that I consider essentially for the student to truly understand and master the subject matter at hand. Memorizing surgical recall lists is akin to memorizing the yellow pages.

All of my students currently have iphones and laptop computers, and many have ipads as well. As we make rounds, they are constantly on the internet via their cell phones looking up answers to my questions, or checking to see if my answers are correct (and sometimes, though rare, they catch a mistake). My medical school has done away for formal lectures in surgery, having posted all the power-point lectures on line so the students may view them (on their computers) at their leisure. Their time on the wards with real "patients" has been limited, and of course they go home if they are "post call". Clearly medical education is changing along with available technology and access to information has changed as well. Whether one may consider this good or bad, it is what it is and it is the way it's going to be in a society that has a Jurassic appetite for information.

The idea that students could have a reliable textbook which could be read in eight weeks that could be simply downloaded appealed to me, and I currently know of no other such text. At the end of each chapter are references to further reading if more detailed information is required of a particular subject. All the references consist of web addresses to full text peer-reviewed articles that are available for free on the internet. Therefore all the materials required for their education in surgery during their medical school years can be downloaded and stored in either an ipad or laptop which is equipped with an internet connection.

During the preparation of this text, obviously going through a large number of full text articles, I found myself both surprised and disappointed. I was astonished at the large volume of material that is currently available on-line. Specifically going through a "Google" search one finds a lot of material geared toward the lay public, and a certain percentage of it is junk and/or pure commercial advertisement. Some sites that have respected quality articles, will only allow a download for a charge of $\$ 30-\$ 60$ per article. Other sites, such as "Pub-Med" are a virtual treasure trove. This is in large part thanks to President Obama signing into law the 2009 Consolidated Appropriations Act which included a provision to make the National Institutes' of Health (NIH) Public Access Policy permanent. In short, all NIH-funded authors are required to deposit electronic copies of their peer-reviewed manuscripts into the National Library of Medicine's online archive, PubMed Central no later than 12 months after publication in a journal. This initially was proposed in 2004 and during the obligatory comment period, met with an outcry from publishers worried about a significant loss of revenue. The percentage of eligible manuscripts deposited has increased obviously, with over 3,000 new manuscripts being deposited each month. The PubMed Central database is a part of a valuable set of public database resources at the NIH, which are accessed by more than 2 million users each day.

The real groundwork for internet access to medical information began in the early 1990's. In 2001 The Budapest Open Access Initiative arose to accelerate progress in the international effort to make research articles in all academic fields freely available on the internet. Stanford University later initiated the High Wire Press, which is an electronic database of full text scholarly non-profit journals freely available on line. Slowly other publishers have joined in, such as the New England Journal of Medicine, making free downloads available on their specific websites. Still many are unavailable or only available for a relatively high charge.

The central argument involving free on-line access to quality scholarly peer-reviewed literature is the ability to guarantee quality via a peer-review process, vs the real cost involved to attain such. It has

Corresponding author: Edwin Earl Gaar MD FACS, Louisville Veterans Administration Medical Center, Office of the Chief of Surgery, Louisville, Kentucky, USA, Tel: 502-894-6802; Fax: 502-894-6825, E-mail: Earl.Gaar@va.gov

Received July 14, 2011; Accepted August 20, 2011; Published December 03 2011

Citation: Gaar EE (2011) The Value and Limitations of Open Access On-line Medical Literature in an Era of Jurassic Information Consumption. Surgery 1:e102. doi:10.4172/2161-1076.1000e102

Copyright: (c) 2011 Gaar EE. This is an open-access article distributed under the terms of the Creative Commons Attribution License, which permits unrestricted use, distribution, and reproduction in any medium, provided the original author and source are credited. 
been estimated that the total cost to publish an article is around $\$ 3000$, a fact that commercial publishing entities are well aware of. They are not interesting in giving away their product and rightly so are focused upon their bottom line. Some journals have countered this by charging a fee to authors, or supplemental fee for the inclusion of color photographs and graphics. Other income is generated by high profile advertising by drug and device manufacturers, as well as institutions announcing employment searches. Also significant revenue comes from licensing agreements. Advertising is a significant expenditure for big equipment and drug manufacturers as direct access to physicians has been slowly but surely closed down under the guise of integrity and transparency as sponsored by the American Medical Association among others, as well as numerous governmental agencies latching onto their coat tails.

Historically our central repository for knowledge has been our libraries. With the information technology revolution, libraries have had to transform themselves but they are not going away anytime in the near future. Many have taken pro-active efforts to position themselves in front of the electronic information explosion. "Everyone now in our digital age, craves access to more electronic information, no matter how much is available, but people treasure efficient methods for extracting pertinent information from the fire-house effect of undifferentiated electronic text (and unwanted commercial offers)," to quote Dr. Donald Lindberg. "Digital librarians will still have a need for digital librarians". Though I like to consider myself as fairly computer literate, I am blessed by a wonderful resourceful library whose librarians have forgotten more about literature searches than I will ever know. Despite everyone having access to the internet attached to their belt, the "library as a place" is still highly valued. With lesser requirements for square footage to house printed paper, more room has become available for people as well as terminals. In addition to serving coffee and light snacks, the best facilities support small-group study, provide well-wired (or wireless) technology, and welcome those seeking a place of respite from patients, wards and buzzing monitors.

In sheer volume, the electronic collections of libraries are becoming vastly larger than the physical collection. Physical collections are slowly dwindling as before the paper fades and deteriorates, they too are becoming digitalized. Efforts such as "Google books" are such an example. Venues for more websites for open access articles still require some sort of peer review process to guard the integrity of the content presented. Having free reign to post "anything" will only disintegrate the integrity of the medical/scientific community. This clearly has a price associated with it and clearly will rely upon creditable volunteers. Clearly these sites will be a welcome niche to authors whose manuscripts might not be a good fit for particular high wire publishing houses. At the same time, publishing houses are going to have to come to the realization that after a certain point, their articles will not sell in significant quantities, especially since print copies are readily available for free from any medical library, and they should establish a time in which they contribute to the dissemination of medical knowledge by making their content free for on-line retrieval following the lead set by the NIH. In our current quest for transparency coupled with our technology revolution, knowledge should be available for all. This only will make us a better society in the future.

\section{References}

1. http://www.nejm.org/doi/full/10.1056/NEJMp068004

2. http://www.nejm.org/doi/full/10.1056/NEJMp048190

3. http://books.google.com/books/about/The_access_principle. html?id=Jo3gAAAAMAAJ

4. http://www.taxpayeraccess.org/issues/nih/index.shtml

5. http://www.plosone.org/article/info:doi/10.1371/journal.pone.0020961

6. http://www.dclab.com/stm_business_model.ASP 